\title{
IDENTIFIKASI SUMBER PENCEMAR DAN ANALISIS KUALITAS AIR TUKAD SABA PROVINSI BALI
}

\author{
Putu Desy Darmasusantini ${ }^{1 *}$, I Nyoman Merit ${ }^{2)}$, I G.B Sila Dharma ${ }^{3)}$ \\ ${ }^{1)}$ Badan Lingkungan Hidup Provinsi Bali \\ ${ }^{2)}$ Fakultas Pertanian UNUD \\ ${ }^{3)}$ Fakultas Perikanan dan Kelautan UNUD \\ *Email : desydarmas@yahoo.com
}

\begin{abstract}
Availability of clean water for drinking water increasingly scarce, then efforts to utilize alternative flow of river water as drinking water and raw water industry one of them is Saba River. Purpose of research is to determine the characteristic of pollution source which will be impactto the changing of water quality in physical, chemical, and biological in up, middle and down stream area of Saba River, water quality and pollution index of Saba River.

Determination of samples by using purposive sampling method. Sampels were taken at six points with repetitions three times at different times. Sampels taken at two points upstream, two points middle and two points downstream. Samples were analyzed in situ and ex situ.

The results showed that the activities that affect water quality physical, chemical, and biological in up, middle and down stream area of Saba River is agricultural activities, livestock, restorant, blacksmith, home stay, residential, workshops, market, laundry and industrial activities. The upstream region until middle region (T1) no parameter exceeded the quality standard, parameters that exceed the quality standard in the middle region (T2) is TSS, BOD, fosfat and fecal coliform, in the downstream which exceeded the parameters in the downstream region (H1) is BOD, fosfat, fecal coliform dan total coliform and in the downstream region (H2) is DO, BOD, COD, fosfat, fecal coliform dan total coliform. Saba River quality status based on the method pollution index in the upstream region (U1) until middle region (T1) showed good condition, middle region (T2) until downstream pollutants classified as mild.
\end{abstract}

Key words: water quality; in situ; ex situ; pollution index

\section{PENDAHULUAN}

Air merupakan sumberdaya alam yang berfungsi sebagai unsur paling esensial, penentu terpenting dalam kehidupan setiap makhluk hidup. Pemanfaatan air untuk berbagai kepentingan harus dilakukan secara bijaksana dengan memperhitungkan kepentingan generasi sekarang dan generasi mendatang (Nugroho, 2008).

Salah satu sumber air yang banyak dimanfaatkan untuk memenuhi kebutuhan hidup manusia dan makhluk hidup lainnya yaitu sungai. Sungai merupakan ekosistem yang sangat penting bagi manusia karena sungai menyediakan air bagi manusia baik untuk berbagai kegiatan seperti pertanian, industri maupun domestik (Siahaan dkk., 2011). Penelitian yang dilakukan Setiari, dkk (2012) menunjukkan limbah akibat aktivitas pertanian, pemukiman, peternakan dan industri menyebabkan penurunan kualitas air. Penurunan kualitas air semakin banyak dirasakan pengaruhnya oleh masyarakat salah satunya adalah banyaknya penyakit yang timbul dan ditularkan melalui air. Penurunan kualitas air akan menurunkan dayaguna, hasil guna, produktivitas, daya dukung dan daya tampung dari sumberdaya air yang pada akhirnya akan menurunkan kekayaan sumberdaya alam.

Tukad Saba merupakan salah satu sungai yang terindikasi mengalami pencemaran karena penurunan kualitas, beberapa parameter yang melampaui baku mutu air kelas satu di Tukad Saba yaitu: BOD, Besi (Fe), Total Fosfat, dan Total Coliform (BLH Prov.Bali, 2013). Daerah Aliran Sungai (DAS) Saba juga mengalami erosi yang tergolong sangat berat di Desa Pujungan dan Desa Subuk (Dewi dkk, 2012).

Tukad Saba merupakan sungai lintas kabupaten yang daerah pengalirannya meliputi Kabupaten Tabanan dan Kabupaten Buleleng. Hulu Tukad Saba berada di Desa Pujungan Kecamatan Pupuan Kabupaten Tabanan dan muaranya berada di Desa Pengastulan Kecamatan Seririt Kabupaten Buleleng. Air Tukad Saba di bendung untuk penyediaan air irigasi, air baku untuk air minum serta pembangkit listrik (Antariza, 2012).

Berdasarkan data tersebut diatas dan kaitannya dengan air Tukad Saba digunakan untuk berbagai kepentingan seperti keperluan domestik, irigasi, air baku air minum dan industri menimbulkan ide 
untuk mengadakan penelitian di Tukad Saba sehingga diketahui tingkat pencemaran yang terjadi sehingga masyarakat lebih menjaga kelestarian sungai dan lebih bijaksana dalam memanfaatkan air sungai.

\section{METODE PENELITIAN}

\subsection{Lokasi Penelitian}

Penelitian ini merupakan penelitian kuantitatif (pengukuran lapangan dan laboratorium). Penentuan titik pengambilan sampel dilakukan dengan cara purposive sampling, yaitu cara penentuan titik pengambilan sampel air dengan melihat pertimbangan-pertimbangan yang dilakukan oleh peneliti antara lain didasari atas kemudahan askes, biaya maupun waktu dalam penelitian.

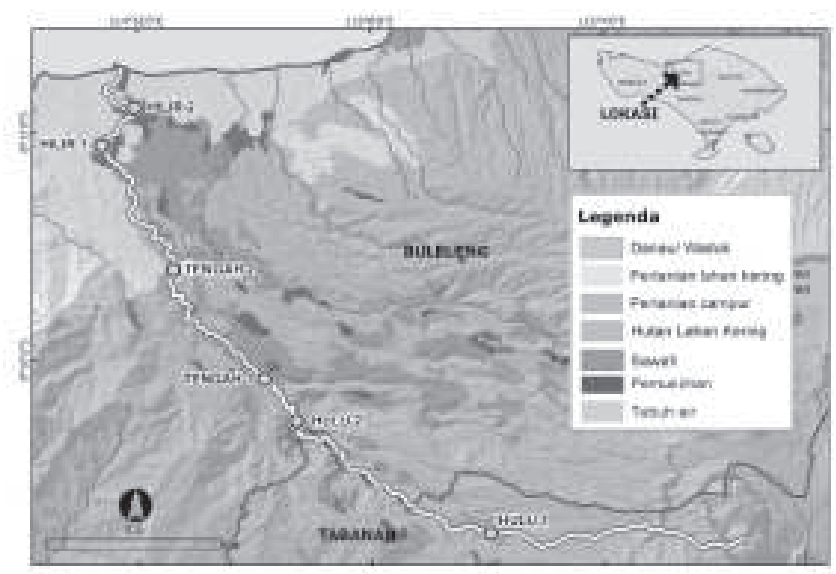

Gambar 1. Peta Lokasi Penelitian (Bappeda Provinsi Bali, 2009)

Pengambilan sampel kualitas air dilakukan pada enam lokasi yaitu: hulu 1 Tukad Saba (U1) : terletak di Desa Pujungan, Kecamatan Pupuan, Tabanan. Hulu 2 Tukad Saba (U2) : terletak di Desa Tinggarsari, Kecamatan Busungbiu, Buleleng. Tengah 1 Tukad Saba (T1) : terletak di Desa Subuk, Kecamatan Busungbiu, Buleleng. Tengah 2 Tukad Saba (T2) : terletak di Desa Titab, Kecamatan Busungbiu, Buleleng. Hilir 1 Tukad Saba (H1) : terletak di Desa Patemon, Kecamatan Seririt, Buleleng. Hilir 2 Tukad Saba (H2) : terletak di Desa Seririt, Kecamatan Seririt, Buleleng. Pengambilan sampel pada enam lokasi diatas diasumsikan dapat mewakili kualitas air Tukad Saba, semakin banyak titik lokasi pengambilan sampel diharapkan data yang dihasilkan dapat lebih representatif.

\subsection{Prosedur Penelitian}

Pengambilan sampel pada air sungai diambil dengan cara pengambilan sampel gabungan (composite sample). Titik pengambilan sampel air sungai ditentukan berdasarkan debit air sungai yang diatur dengan ketentuan sebagai berikut: 1) sungai dengan debit kurang dari $5 \mathrm{~m}^{3} /$ detik, sampel diambil pada satu titik ditengah sungai pada kedalaman 0,5 kali kedalaman dari permukaan; 2) sungai dengan debit antara $5 \mathrm{~m}^{3} /$ detik - $150 \mathrm{~m}^{3} /$ detik, sampel diambil pada dua titik masing-masing pada jarak 1/3 dan 2/ 3 lebar sungai pada kedalaman 0,5 kali kedalaman dari permukaan kemudian dicampurkan; 3) sungai dengan debit lebih dari $150 \mathrm{~m}^{3} /$ detik, contoh diambil minimum pada enam titik masing-masing pada jarak 1/4, 1/2, dan 3/4 lebar sungai pada kedalaman 0,2 dan 0,8 kali kedalaman dari permukaan lalu dicampurkan (Badan Standarisasi Nasional, 2008).

Penentuan sampel wawancara menggunakan teknik disproportionate stratified random sampling. Teknik ini digunakan untuk menentukan jumlah sampel bila populasi berstrata tetapi kurang proporsional, aktivitas manusia yang diidentifikasi berjumlah sedikit maka sampel tersebut diidentifikasi semua (Sugiyono, 2014).

\section{HASIL DAN PEMBAHASAN}

\subsection{Karakteristik Sumber Pencemar}

Wilayah hulu meliputi Desa Pujungan, Desa Pupuan, Desa Tinggarsari. Sumber pencemar di wilayah hulu di dominasi oleh pertanian dan tegalan. Lahan tegalan lebih luas dibandingkan dengan persawahan. Kegiatan pertanian berbatasan langsung dengan sungai. Pemukiman penduduk pada daerah ini sangat jarang dan letaknya relatif jauh dari daerah aliran sungai tetapi tidak menutup kemungkinan limbah yang mereka hasilkan masuk ke badan air. Air Tukad Saba dimanfaatkan untuk mengairi sawah, tegalan, tempat mandi, cuci dan kakus. Limbah yang dihasilkan dari pertanian berupa sisa-sisa pupuk hanyut terbawa aliran air masuk ke sungai dan aktivitas MCK dapat mencemari sungai. Sumber pencemar yang lain yaitu peternakan skala rumah tangga, pasar, bengkel, laundry, penginapan, kerajinan logam, pencucian mobil dan sepeda motor dan pemotongan ternak.

Wilayah tengah meliputi Desa Bantiran, Desa Subuk, Desa Kekeran, Desa Titab, Desa Busungbiu, Desa Ularan. Sumber pencemar pada daerah ini pasar, bengkel, laundry, restoran/rumah makan, peternakan ayam, penginapan, dan kerajinan logam. Pada wilayah ini terdapat 1 unit peternakan ayam yang cukup besar. Kegiatan usaha peternakan menghasilkan limbah padat, cairan, gas maupun sisa pakan. Limbah padat (kotoran ternak, ternak yang mati, atau isi perut dari pemotongan ternak). Limbah cair adalah semua cairan (air seni atau urine, air dari pencucian kandang), sedangkan limbah gas berasal dari kotoran ternak. Beragam aktivitas yang terjadi di sepanjang Tukad Saba dapat meningkatkan parameter kualitas lingkungan. Semua aktivitas yang terjadi di wilayah tengah ini tidak dilakukan pengelolaan limbah dan pembuangan sampah ke sungai. Pencemaran akibat aktivitas 
manusia menyebabkan peningkatan indikator pencemaran seperti BOD, COD serta bakteri coli dalam sungai.

Wilayah hilir meliputi Desa Ringdikit, Desa Lokapaksa, Desa Patemon, Desa Seririt dan Desa Pengastulan. Sumber pencemar di wilayah hilir di dominasi oleh pemukiman padat penduduk, letak pemukiman ini sangat berdekatan dengan daerah aliran sungai terutama di Desa Patemon, Desa Seririt dan Desa Pengastulan. Kepadatan penduduk sangat berpengaruh terhadap limbah yang dihasilkan. Limbah cair yang dihasilkan dari rumah tangga merupakan jenis limbah domestik. Selain limbah domestik, pasar, limbah pabrik tahu dan tempe, bengkel, kerajinan logam, laundry, peternakan dalam skala rumah tangga dan pencucian mobil juga dapat mempengaruhi kualitas air Tukad Saba. Industri tahu dan tempe di wilayah ini masih merupakan industri kecil skala rumah tangga yang belum dilengkapi unit pengolahan limbah. Industri tahu dan tempe dapat menghasilkan limbah cair dari bekas air pencucian bahan baku pembuat tahu dan tempe dan limbah padat berupa ampas. Limbah padat berupa ampas sudah dimanfaatkan untuk pakan ternak sedangkan limbah cair dibuang begitu saja ke sungai. Pollutan yang dihasilkan dari aktivitas industri tahu dan tempe berupa pollutan organik seperti karbohidrat dan protein.

\subsection{Hasil Analisis Parameter Fisika Kualitas Air Tukad Saba}

Deskripsi kualitas air Tukad Saba menurut parameter, lokasi dan tahap pengambilan adalah sebagai berikut:

\subsubsection{Debit dan suhu}

Debit sungai dipengaruhi oleh hujan, topografi, geologi, keadaan tumbuh-tumbuhan dan manusia (Soebarkah, 1978). Debit air Tukad Saba pada wilayah hilir lebih kecil dibandingkan dengan wilayah tengah karena pada wilayah tengah 2 (Desa Titab) air Tukad Saba dibendung sehingga air yang melimpah memiliki debit $3,45 \mathrm{~m}^{3} / \mathrm{dt}$, setelah melewati Waduk Titab di Desa Titab air Tukad Saba kembali di bendung di Desa Lokapaksa (Bendung Saba), pada lokasi ini air Tukad Saba dialirkan melalui pintu sadap ke saluran-saluran pembagi untuk mengairi Subak Baru dan Subak Lama. Saluran-saluran ini tidak terhubung kembali ke Tukad Saba. Air Tukad Saba kembali di bendung di Desa Patemon (Bendung Puluran) untuk mengairi Subak Karangsari dan Subak Puluran, saluran-saluran pembagi ini juga tidak terhubung kembali ke Tukad Saba sehingga debit air menjadi kecil di wilayah hilir.

Suhu badan air dipengaruhi oleh musim, lintang (latitude), ketinggian dari permukaan laut (altitude), waktu dalam hari, sirkulasi udara, penutupan awan, dan aliran serta kedalaman badan air (Effendi, 2003). Peningkatan dan penurunan suhu dalam air dipengaruhi oleh komposisi substrat, kekeruhan, curah hujan, angin, suhu limbah dan reaksi-reaksi kimia yang terjadi dalam air (Suyasa, 2015). Berdasarkan hasil penelitian suhu mengalami peningkatan dari hulu ke hilir, pada wilayah hulu merupakan daerah pegunungan sehingga suhu udara pada wilayah ini rendah sedangkan pada wilayah hilir dekat dengan laut sehingga suhu udara tinggi, suhu udara mempengaruhi suhu badan air. Pada wilayah hilir (Desa Seririt) juga terdapat industri tahu dan tempe, limbah tahu dan tempe yang berasal dari air rebusan kedelai dapat menyebabkan peningkatan suhu air Tukad Saba.

\subsubsection{TDS dan DHL}

Daya hantar listrik merupakan kemampuan cairan untuk menghantarkan arus listrik. Semakin baanyak garam - garam terlarut yang dapat terionisasi, semakin tinggi pula nilai DHL. Nilai DHL air Tukad Saba memiliki kecendrungan meningkat dari hulu ke hilir dan nilai DHL berhubungan erat dengan nilai padatan terlarut total (TDS). Nilai TDS biasanya lebih kecil daripada nilai DHL (Effendi, 2003). Pola distribusi DHL menurut lokasi juga serupa dengan pola distribusi TDS. Kondisi ini menunjukkan bahwa semakin kearah hilir maka semakin besar kemampuan kation dan anion yang terdapat dalam air untuk menghantarkan arus listrik yang mengindikasikan bahwa semakin banyak mineral yang terkandung dalam air.

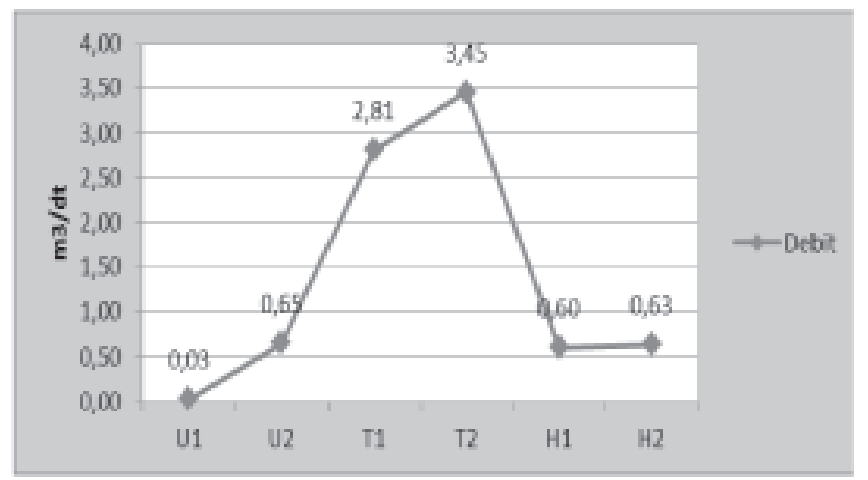

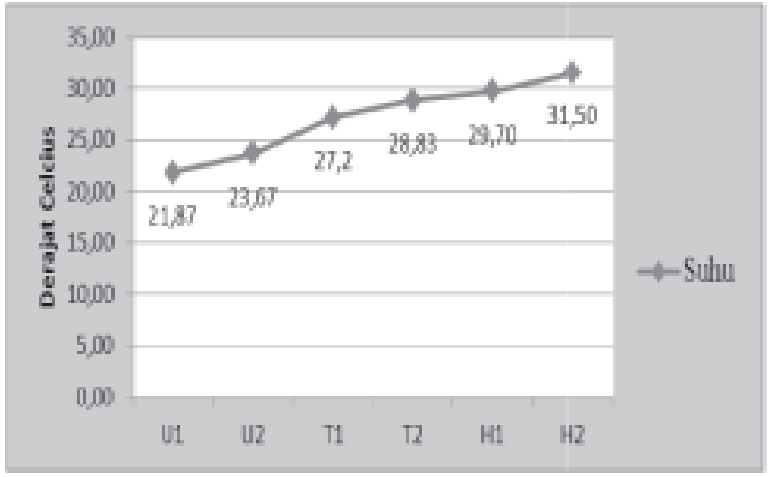

Gambar 2. Rata-rata Debit dan Suhu Air Tukad Saba menurut Wilayah Pengambilan Sampel 

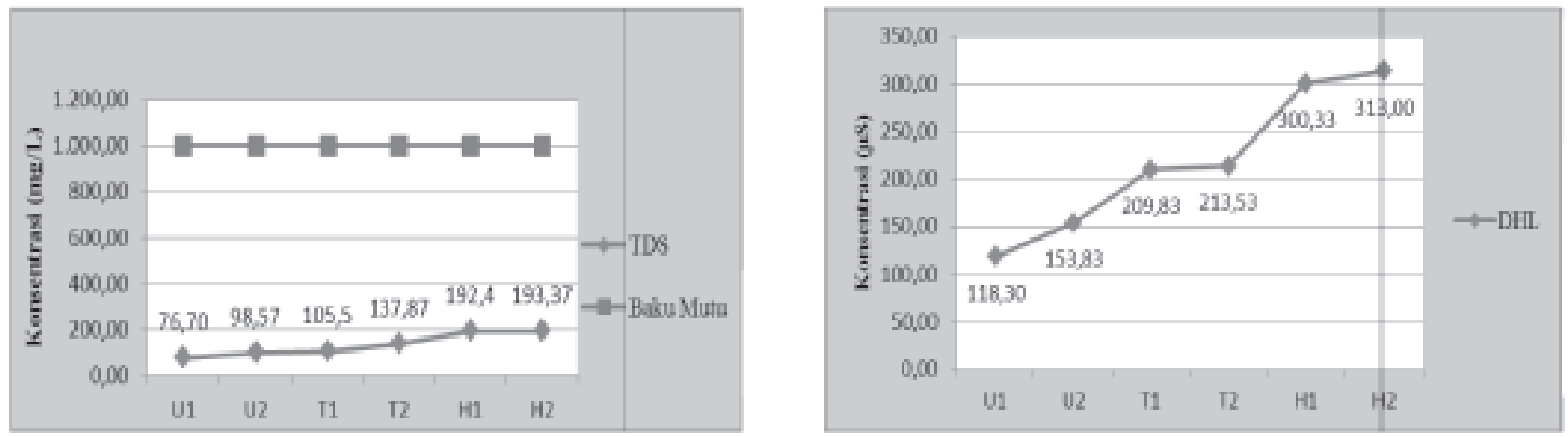

Gambar 3. Rata-rata Konsentrasi TDS dan DHLAir Tukad Saba menurut Wilayah Pengambilan Sampel 3.2.3 TSS dan kekeruhan
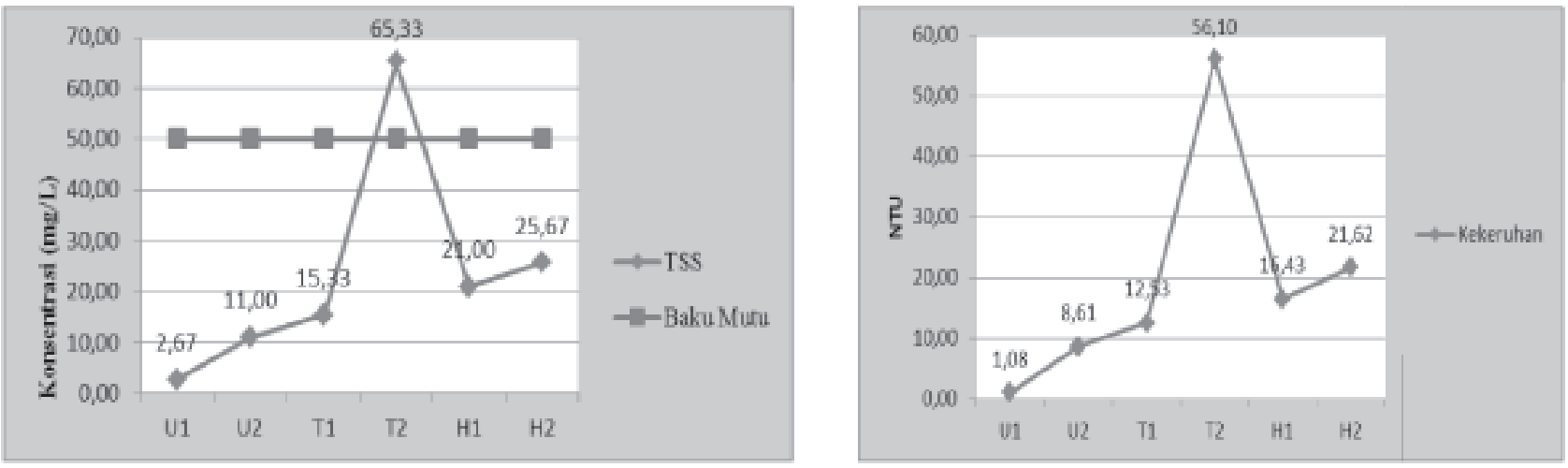

Gambar 4. Rata-rata Konsentrasi TSS dan Kekeruhan Air Tukad Saba menurut Wilayah Pengambilan Sampel

Konsentrasi TSS menggambarkan jumlah bobot bahan yang tersuspensi dalam suatu volume air tertentu (Sastrawijaya, 2009). Suatu kenaikan mendadak padatan tersuspensi dapat ditafsirkan karena erosi tanah mengingat pada lokasi ini terjadi pembangunan Waduk Titab, aktivitas pengerukan tanah pada pembangunan waduk menyebabkan tanah masuk ke badan air serta derasnya aliran air juga mempengaruhi meningkatnya konsentrasi padatan tersuspensi.

Kekeruhan menggambarkan sifat optik air yang ditentukan berdasarkan banyaknya cahaya yang diserap dan dipancarkan oleh bahan-bahan yang terdapat di dalam air (Davis dan Cornwell, 1991). Padatan tersuspensi berkorelasi positif dengan kekeruhan. Semakin tinggi nilai padatan tersuspensi nilai kekeruhan juga semakin tinggi, konsentrasi kekeruhan tahap I - III dibawah baku mutu yang ditetapkan yaitu sebesar $1.000 \mathrm{mg} / \mathrm{L}$.

\subsection{Hasil Analisis Parameter Kimia Kualitas Air Tukad Saba}

\section{$3.3 .1 \mathrm{pH}$}

Nilai $\mathrm{pH}$ diatas 7 menunjukkan bahwa air Tukad Saba dalam keadaan basa, ini disebabkan karena limbah domestik yang dihasilkan bersifat basa dan Tukad Saba dipergunakan untuk aktivitas MCK. Sabun dan deterjen bersifat basa sehingga apabila dipergunakan menyebabkan air dalam keadaan basa.
Biota akuatik menyukai pH antara $7-8,5$ (Sumantri, 2010).

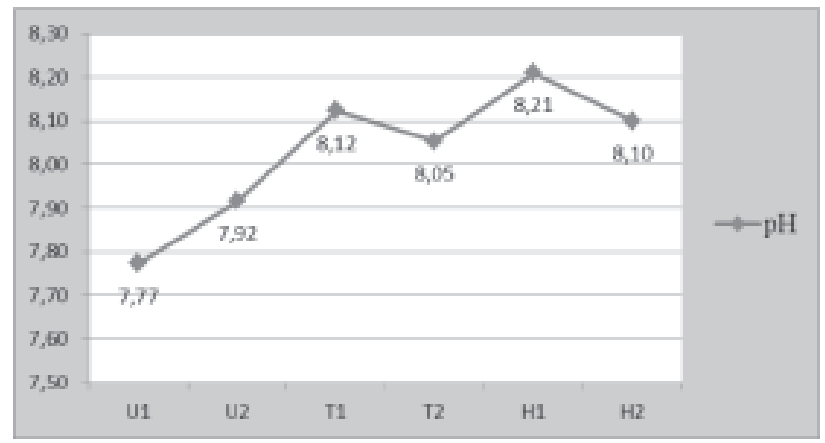

Gambar 5. Rata-rata Konsentrasi pH Air Tukad Saba menurut Wilayah Pengambilan Sampel

3.3.2. Kebutuhan oksigen biokimia (BOD) dan Oksigen terlarut (DO)

Rata-rata konsentrasi BOD air Tukad Saba memperlihatkan peningkatan BOD dari hulu (Desa Pujungan) ke hilir (Desa Seririt). Konsentrasi BOD melampaui baku mutu air kelas I mulai terpantau di Desa Titab dan berlanjut sampai ke hilir. Meningkatnya konsentrasi BOD di wilayah hilir disebabkan karena wilayah hilir merupakan kawasan padat pemukiman dan masyarakat memiliki perilaku membuang sampah ke Tukad Saba. Pada wilayah hilir 2 (Desa Seririt) memiliki 
konsentrasi BOD tertinggi ini disebabkan karena pada wilayah ini selain pemukimannya yang padat, aktivitas pasar yang berdekatan dengan Tukad Saba dan adanya pabrik tahu dan tempe yang membuang limbahnya ke Tukad Saba. Limbah ini mengandung bahan organik yang tinggi terutama protein, karbohidrat, lemak dan asam amino sehingga berkontribusi sangat besar terhadap meningkatnya konsentrasi BOD.

Berdasarkan hasil penelitian konsentrasi DO di H2 melampaui baku mutu yang ditetapkan ini disebabkan oleh tingkat turbulensi air yang semakin kecil dan suhu air yang semakin meningkat berpengaruh terhadap pelemahan kelarutan oksigen. Semakin tinggi suhu air maka kelarutan dan daya larut oksigen semakin rendah. Perairan yang turbulensinya tinggi akibat adanya arus dan angin maka daya larut oksigen semakin tinggi. Selain karena faktor kelarutan, penurunan oksigen terlarut kearah hilir juga dipengaruhi oleh adanya peningkatan beban oksidasi dari bahan-bahan organik atau bahan-bahan penurun oksigen seperti limbah deterjen, limbah MCK, limbah dari pabrik tahu dan tempe, sehingga semakin ke hilir semakin banyak oksigen yang dibutuhkan untuk mengoksidasi bahan-bahan organik oleh mikroorganisme.

\subsubsection{Kebutuhan oksigen kimiawi (COD) dan Fosfat}

Konsentrasi COD melampaui baku mutu air kelas I maksimal $10 \mathrm{mg} / \mathrm{L}$ hanya terdapat di lokasi hilir 2 (Desa Seririt). Sementara COD di lokasi lainnya berada di bawah baku mutu. Kondisi ini menunjukkan bahwa semakin ke hilir terjadi peningkatan beban pencemaran bahan-bahan organik biodegradable dan non-biodegradable.

Rata-rata konsentrasi fosfat menurut lokasi berkisar $0,08-0,50 \mathrm{mg} / \mathrm{L}$, mengalami peningkatan dari hulu kearah hilir. Rata-rata konsentrasi fosfat sudah menunjukkan konsentrasi yang tinggi dan melampaui baku mutu air kelas I di Desa Titab dan mengalami lonjakan kearah hilir. Hal ini disebabkan karena petani pada wilayah ini lebih banyak menggunakan pupuk buatan $(\mathrm{N}, \mathrm{P}, \mathrm{K})$ dan pestisida dalam menggarap sawah sehingga limbah yang dihasilkan masuk ke sungai. Penggunaan deterjen untuk mencuci dapat meningkatkan konsentrasi fosfat diperairan. Polifosfat dari detergen ini diperkirakan memberikan kontribusi sekitar 50\% dari seluruh fosfat yang terdapat di perairan (Effendi, 2003).
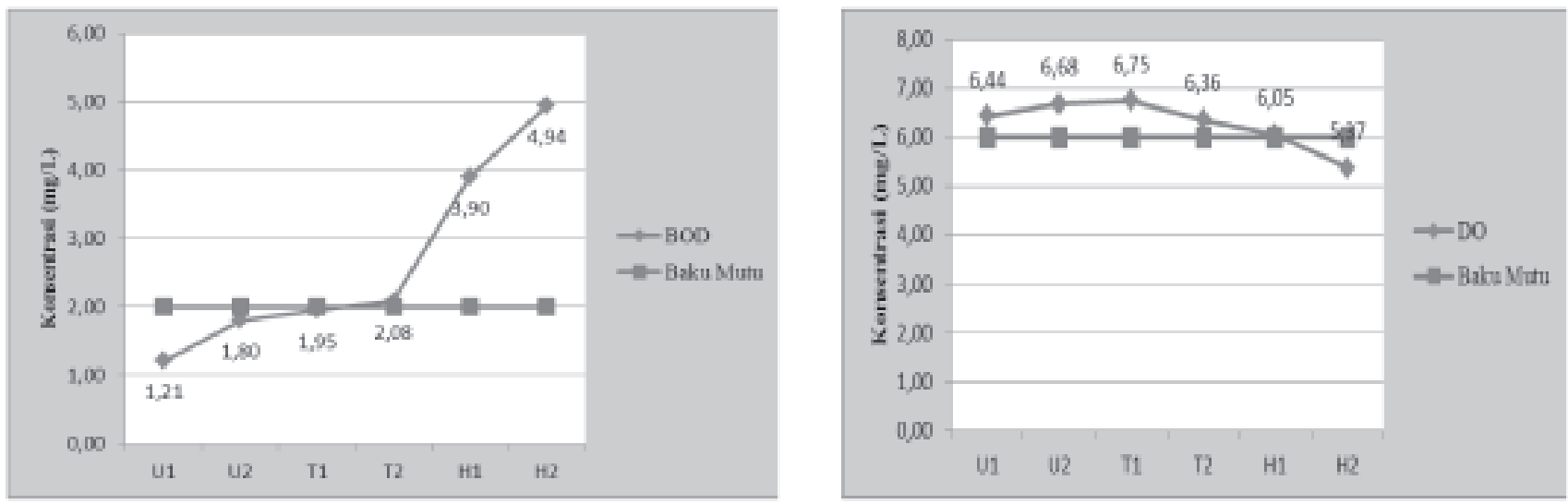

Gambar 6. Rata-rata Konsentrasi BOD dan DO Air Tukad Saba menurut Wilayah Pengambilan Sampel
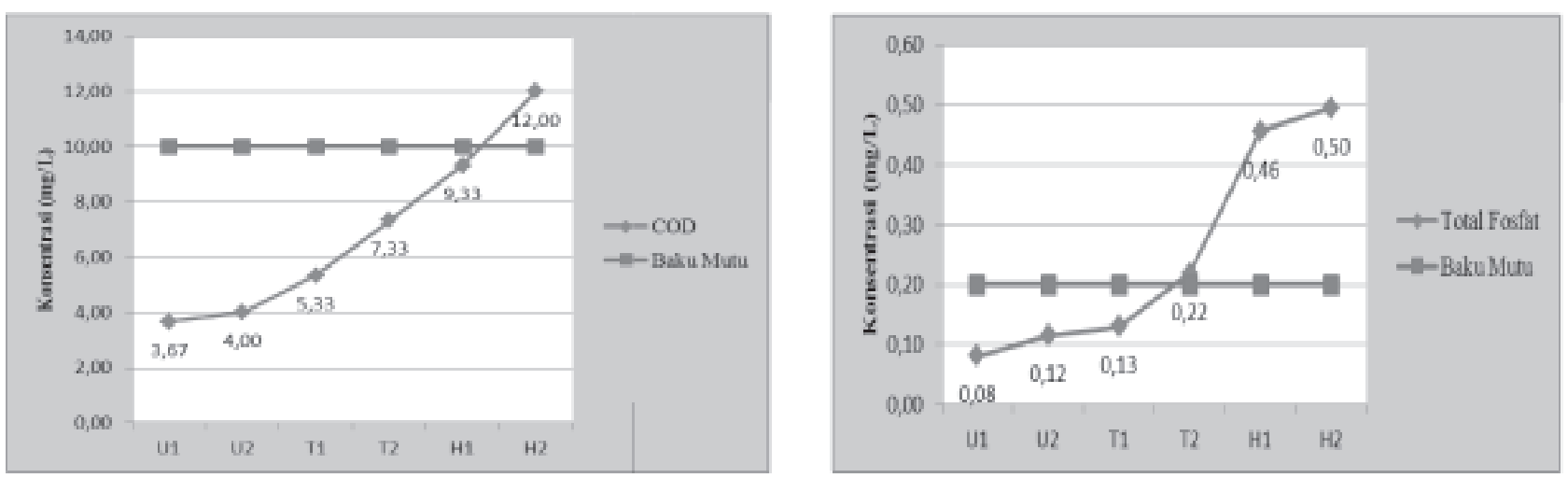

Gambar 7. Rata-rata Konsentrasi COD dan Total Fosfat Air Tukad Saba menurut Wilayah Pengambilan Sampel 

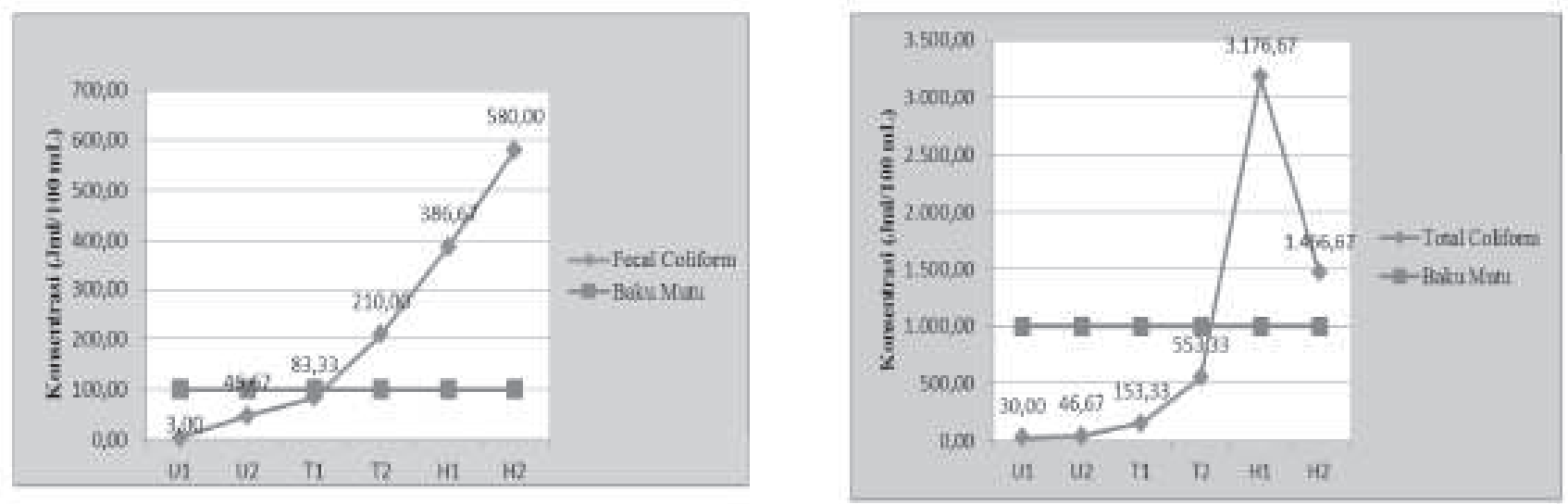

Gambar 8. Konsentrasi Fecal Coliform dan Total Coliform Air Tukad Saba menurut Wilayah dan Tahap Pengambilan Sampel

\subsection{Hasil Analisis Parameter Biologi Kualitas Air Tukad Saba}

\subsubsection{Fecal coliform dan total coliform}

Terdapat peningkatan konsentrasi fecal coliform yang konsisten sepanjang aliran dengan peningkatan cukup tinggi di hilir 2 (Desa Seririt). Rata-rata konsentrasi fecal coliform melampaui baku mutu air kelas I mulai terdapat di Desa Titab kearah hilir. Hal ini menunjukkan bahwa air Tukad Saba di bagian tengah 2 dan hilir telah tercemar oleh fecal coliform. Pencemaran fecal coliform di perairan ini bersumber dari aliran limbah domestik dari permukiman sekitarnya, limbah kotoran ternak dan pemanfaatan sungai langsung untuk cuci dan kakus.

Peningkatan beban pencemar mengandung tinja semakin ke hilir semakin meningkat karena aktivitas peternakan seperti pembersihan kandang dan pembuangan kotoran ternak langsung ke sungai, limbah domestik yang masuk ke sungai dan pemanfaatan sungai langsung untuk cuci dan kakus semakin banyak. Adanya peternakan 1 unit yang ada di Desa Busungbiu, peternakan skala rumah tangga dan pemukiman yang sangat padat di daerah hilir menyebabkan peningkatan konsentrasi fecal coliform dan total coliform yang cukup signifikan pada daerah hilir. Bakteri coliform di bedakan menjadi dua golongan yaitu bakteri golongan fekal dan bakteri non fekal. Bakteri coliform merupakan golongan mikroorganisme pembusuk.

\subsection{Status Mutu Air Tukad Saba}

Hasil analisis indeks pencemaran (IP) terhadap hasil pengambilan sampel air Tukad Saba untuk menentukan status mutu air menunjukkan bahwa status mutu air Tukad Saba menurut lokasi pengambilan terdiri atas kondisi baik sampai cemar ringan jika dibandingkan dengan baku mutu air Kelas I. Dua lokasi dengan status mutu baik yaitu Desa Pujungan dan Desa Tinggarsari. Empat lokasi dengan status mutu cemar ringan yaitu Desa Subuk, Desa Titab, Desa Patemon dan Desa Seririt.
Nilai IP dari hulu ke hilir meningkat, di hulu sebesar 0,45 kearah hilir sebesar 3,62. Berdasarkan status mutu, kondisi air Tukad Saba mengalami penurunan mutu secara signifikan dari hulu kearah hilir, sebagaimana sungai-sungai lainnya, mutu air Tukad Saba utamanya dipengaruhi oleh bahan-bahan organik, fosfat dan limbah tinja. Pencemar bahanbahan organik mendorong kerja bakteri aerobik sehingga meningkatkan kebutuhan oksigen dalam air serta menghasilkan senyawa turunannya berupa nitrit. Pada daerah hilir, air Tukad Saba telah terkontaminasi kadar koli tinja dan total koli yang relatif tinggi. Pola pemanfaatan lahan di sekitar sungai dan pemanfaatan sungai sehari-harinya berkontribusi terhadap tingginya kadar koli tinja dan total koli. Kedua parameter ini paling utama mendegradasi mutu air Tukad Saba di daerah hilir.

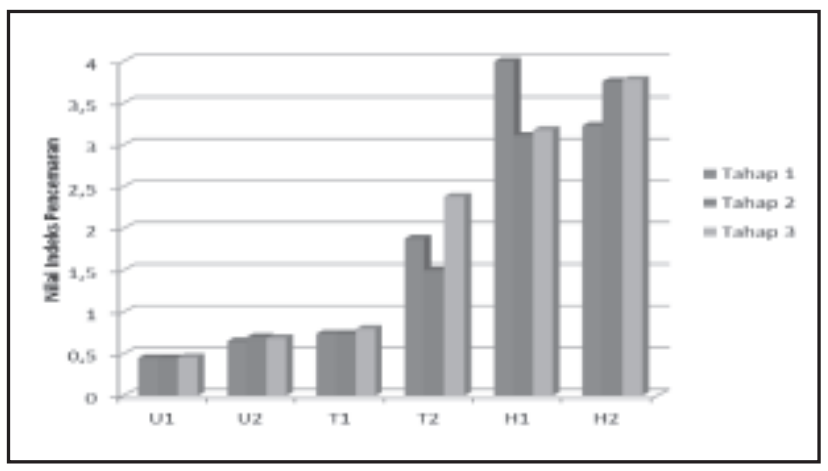

Gambar 9. Persebaran Nilai Indeks Pencemaran Tukad Saba

\section{SIMPULAN DAN SARAN}

\subsection{Simpulan}

1. Karakteristik sumber pencemar yang mempengaruhi kualitas air secara fisik, kimia, dan biologi pada hulu, tengah dan hilir Tukad Saba adalah kegiatan pertanian, peternakan, restoran, kerajinan logam, penginapan, pemukiman, bengkel, pasar, laundry dan kegiatan industri. 
2. Kualitas air Tukad Saba secara fisik, kimia, dan biologi pada wilayah hulu dan tengah 1 (Desa Subuk) tidak ada parameter yang melampaui baku mutu kelas I. Pada wilayah di Desa Titab (T2) parameter TSS, BOD, fosfat dan fecal coliform telah melampaui baku mutu, sedangkan pada wilayah hilir parameter yang melampaui baku mutu di Desa Patemon (H1) adalah BOD, fosfat, fecal coliform dan total coliform, serta di Desa Seririt (H2) adalah DO, BOD, COD, fosfat, fecal coliform dan total coliform.

3. Status mutu Tukad Saba berdasarkan Metode Indeks Pencemaran pada wilayah hulu dan tengah 1 menunjukkan kondisi baik, tengah 2 dan hilir tergolong cemar ringan. Aktivitas manusia sangat mempengaruhi perubahan kualitas air Tukad Saba, semakin banyak jenis aktivitas yang terjadi maka kualitas air Tukad Saba semakin menurun.

\subsection{Saran}

1. Kualitas air di Tukad Saba dapat terus terpelihara, dengan adanya kesadaran masingmasing aktivitas untuk meminimalisasi limbah yang dihasilkan dan mengadakan pengolahan limbah minimal pada tahap awal (primer), misalnya dengan cara pengendapan.

2. Pembuatan biogas pada wilayah tengah dapat mengatasi pencemaran akibat limbah kotoran ternak dan manusia.

3. Perlu adanya pendataan dan pengawasan terhadap aktivitas yang terjadi di sepanjang daerah aliran sungai.

4. Penelitian secara periodik perlu dilakukan untuk memperoleh gambaran kualitas Air Tukad Saba mengingat fungsinya sebagai penyedia air baku air minum.

\section{DAFTAR PUSTAKA}

Antariza, I.G.N. 2014. Simulasi dan Optimasi Harga Air Bersih Pada Proyek Waduk Titab Kabupaten Buleleng Propinsi Bali. Available from: URL:http://jurnalpengairan.ub.ac.id/index.php/ jtp/article/download/136/135diakses 30/8/2014.

Badan Lingkungan Hidup Provinsi Bali. 2013. Status Lingkungan Hidup Daerah. Denpasar.
Badan Perencanaan Pembangunan Daerah Provinsi Bali. 2009. Rencana Tata Ruang Wilayah Provinsi Bali. Denpasar.

Badan Standarisasi Nasional. 2008. Metode Pengambilan Contoh Air Permukaan. SNI 6989.57.2008.

Davis, M.L. and D.A. Cornwell. 1991. Introduction to Environmental Engineering. Second edition. Mc-Graw-Hill, Inc. New York.

Dewi, I.G.A.S.U., Trigunasih N.M., Kusumawati T.2012. "Prediksi Erosi dan Perencanaan Konservasi Tanah dan Air pada DAS Saba".Jurnal Agroekoteknologi Tropika, Vol. 1(1) : 15-20.

Effendi, H. 2003. Telaah Kualitas Bagi Pengelolaan Sumber Daya dan Lingkungan Perairan. Yogyakarta : Kanisius.

Nugroho, S.P. 2008. "Analisis Kualitas Air Danau Kaskade Sebagai Sumber Imbuhan Waduk Resapan diKampus UI Depok". Jurnal Sains dan Teknologi Indonesia, 10: 99-105.

Sastrawijaya, A.T. 2009. Pencemaran Lingkungan. Rineka Cipta. Jakarta

Setiari, N.M., Mahendra M.S., Suyasa W.B. 2012."Identifikasi Sumber Pencemar dan Analisis Kualitas Air Tukad Sungi di Kabupaten Tabanan dengan Metode Indeks Pencemaran”. Jurnal Ecotrophic, Vol. 7(1): 40-46.

Siahaan, R., A. Indawan, D. Soedharma, dan L.B. Prasetyo. 2011. "Kualitas Air Sungai Cisadane, Jawa Barat-Banten". Jurnal Ilmiah Sains, 11: 268-273.

Soebarkah. I. 1978. Hidrologi untuk Perencanaan Bangunan Air. Idea Dharma. Bandung.

Sugiyono. 2014. Statistika untuk Penelitian. Alfabeta. Bandung.

Sumantri. A. 2010. Kesehatan Lingkungan. Kencana Prenada Media Group. Jakarta. 